\title{
On dendrites in Down syndrome and DS murine models: a spiny way to learn
}

\author{
R. Benavides-Piccione ${ }^{\mathrm{a}, 1}$, I. Ballesteros-Yáñez ${ }^{\mathrm{a}, 1}$, M. Martínez de Lagrán ${ }^{\mathrm{b}, 2}$,

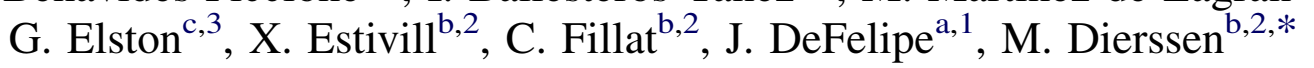 \\ ${ }^{a}$ Cajal Institute, 28002 Madrid, Spain \\ ${ }^{\mathrm{b}}$ Program in Genes and Disease, Genomic Regulation Center, 08003 Barcelona, Spain \\ ${ }^{\mathrm{c}}$ Vision, Touch and Hearing Research Centre, School of Biomedical Sciences, Queensland Brain Institute, \\ The University of Queensland, 4072, Australia
}

Received 11 March 2004; accepted 2 August 2004

\begin{abstract}
Since the discovery in the 1970s that dendritic abnormalities in cortical pyramidal neurons are the most consistent pathologic correlate of mental retardation, research has focused on how dendritic alterations are related to reduced intellectual ability. Due in part to obvious ethical problems and in part to the lack of fruitful methods to study neuronal circuitry in the human cortex, there is little data about the microanatomical contribution to mental retardation. The recent identification of the genetic bases of some mental retardation associated alterations, coupled with the technology to create transgenic animal models and the introduction of powerful sophisticated tools in the field of microanatomy, has led to a growth in the studies of the alterations of pyramidal cell morphology in these disorders. Studies of individuals with Down syndrome, the most frequent genetic disorder leading to mental retardation, allow the analysis of the relationships between cognition, genotype and brain microanatomy. In Down syndrome the crucial question is to define the mechanisms by which an excess of normal gene products, in interaction with the environment, directs and constrains neural maturation, and how this abnormal development translates into cognition and behaviour. In the present article we discuss mainly Down syndrome-associated dendritic abnormalities and plasticity and the role of animal models in these studies. We believe that through the further development of such approaches, the study of the microanatomical substrates of mental retardation will contribute significantly to our understanding of the mechanisms underlying human brain disorders associated with mental retardation.
\end{abstract}

(C) 2004 Elsevier Ltd. All rights reserved.

\section{Contents}

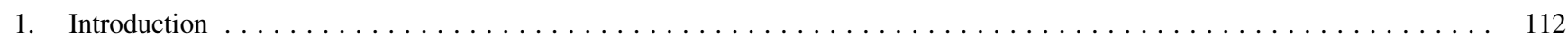

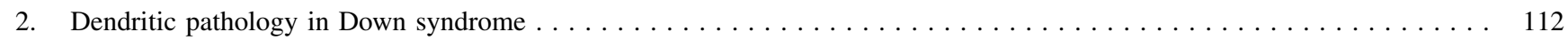

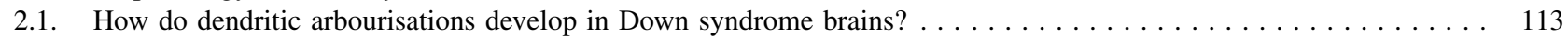

2.2. Genetic control of dendritic maturation: what is wrong in Down syndrome? . . . . . . . . . . . . . . 114

Abbreviations: DS, Down syndrome; SIM2, single-minded homolog 2; DYRK1A, dual-specificity tyrosine-Y-phosphorylation kinase; GART, phosphoribosylglycinamideformyltransferase; PCP4, Purkinje cell protein 4; DSCAM, Down syndrome cell adhesion molecule; APP, amyloid beta A4 precursor; S100B, calcium binding protein beta; SOD1, superoxide dismutase 1; DSCR1, Down syndrome critical region 1; ITSN, intersectin

* Corresponding author. Tel.: +34 93224 0900; fax: +34 932240899.

E-mail address: g.elston@vthrc.uq.edu.au (G. Elston), defelipe@cajal.csic.es (J. DeFelipe), mara.dierssen@crg.es (M. Dierssen).

1 Tel.: +3491585 4735; fax: +34915854754.

2 Tel.: +3493224 0900; fax: +34932240899.

3 Tel.: +61 733654108 ; fax: +67 733654522 . 
3. The neural phenotype in animal models for Down syndrome: what do we know? $\ldots \ldots \ldots \ldots \ldots$

4. Pharmacological and non-pharmacological strategies targeting cognitive functions treatments: can we change Down

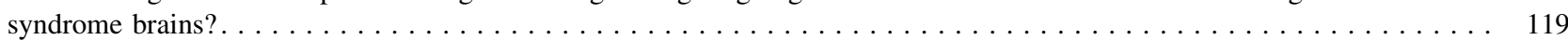

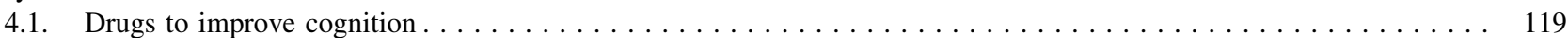

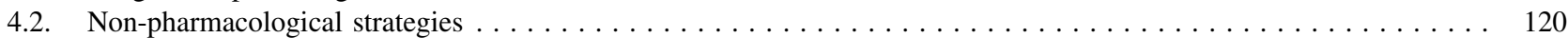

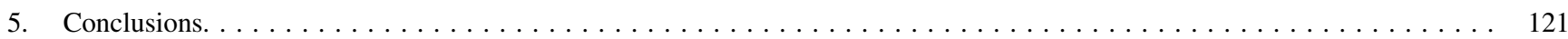

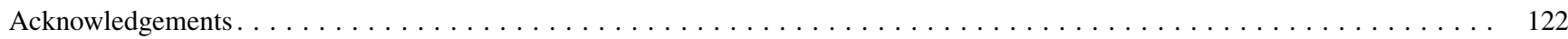

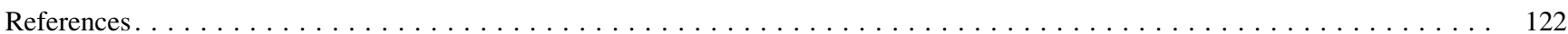

\section{Introduction}

The biological bases for mental retardation are poorly understood, but defects in neuronal network formation or in properties of brain plasticity likely contribute to the cognitive impairment. Down syndrome (DS) is the most common genetic disorder associated with mental retardation (Hassold and Jacobs, 1984; Mastroiacovo, 2002) and its phenotypic characteristics are believed to stem from the overexpression of a set of genes on human chromosome 21 . Thus, studies of the DS population provide a rare opportunity to examine relationships between cognition, genotype and brain neurobiology. In patients with DS, mental retardation is moderate and the intelligence coefficient ranges between 20 and 80 (Anneren and Pueschel, 1996). The rate of cognitive development tends to slow as children with DS grow older so that the brain undergoes a progressive postnatal degenerative process.

The neuropathological correlates of these impairments are still under intensive investigation. In subjects with DS, brain size and weight are moderately reduced at birth. Specific brain areas exhibit an immature gyral pattern, neocortical laminar formation is irregular and myelination of cortical fibres is delayed (Kemper, 1988; Golden and Hyman, 1994; Wisniewski and Kida, 1994). Data obtained from studies that have utilized functional neuroimaging techniques have expanded our knowledge of the neuroanatomical basis of brain malfunctioning in DS brains and provided initial clues as to the specific defects that occur during neural development. The advent of in vivo structural brain imaging will not only help researchers identify which brain structures are implicated in specific neurobehavioural conditions but also may discover individual variations among persons with the same genetic defect. Using magnetic resonance imaging (MRI), Raz et al. (1995) showed that young adult DS subjects have reduced volumes of cerebral and cerebellar hemispheres, ventral pons, mammillary bodies, and hippocampal formation, even after adjustment for body size. In contrast, the parahippocampal gyrus is enlarged and frontal lobe volumes are disproportionately smaller in DS (Pinter et al., 2001). Functional imaging with positron emission tomography (PET) shows cerebral metabolic rates for glucose in young DS adults, with fewer significant correlations in different brain regions than in controls, suggesting that functional connections between brain circuit elements are reduced leading to dysfunctional circuitry in adults (Shapiro et al., 1992).

At the microscopic level, neuronal density is decreased in distinct regions of DS brains, including the cochlear nuclei, cerebellum, hippocampus, basal forebrain, the granular layers of the neocortex and areas of the brainstem. In the neocortex, neuronal morphology is abnormal and neuronal orientation is aberrant (reviewed in Flórez, 1992). Other studies have reported reductions in cortical width, abnormal cortical lamination patterns, altered dendritic arbours and dendritic spines, aberrant electrophysiological properties of membranes, reduced synaptic density and abnormal synaptic morphology in DS foetuses (Becker et al., 1986, 1991; MarinPadilla, 1976; Suetsugu and Mehraein, 1980, see also Section 1.1). Some of these alterations may be related to an abnormal development of the nervous system during pre- and post-natal life. However, it is difficult to attribute the cognitive alterations in DS to a simple reduction of brain size or neuronal density. In fact, neuronal cell structure does not correlate with differences in brain size. Instead, different aspects of neuronal cell structure such as the size of the basal dendritic arbours, their branching structure, and spine density may vary independently (see Elston, 2003a for a review).

\section{Dendritic pathology in Down syndrome}

Neural mechanisms underlying mental retardation may include defects in the formation of neuronal networks and/or in information processing aspects of brain plasticity. Dendritic pathology is a consistent feature and substrate of mental retardation across multiple conditions suggesting that dendritic abnormalities are an index of major neuronal disruption (reviewed in Kaufmann and Moser, 2000) and that dendritic architecture determines the nature of a neurone's inputs and its role in cortical circuitry (Friedlander et al., 1982; Bacon and Murphey, 1984). In DS, the pathogenesis of dendritic abnormalities is distinctive and appears to correlate to some extent with cognitive profile. 
Both abnormal postnatal development, and remodelling of the brain circuitry could contribute to observed dendritic abnormalities in DS, with serious consequences on the cognitive abilities. However, if the severity and extent of dendritic alterations correlates with cognitive function, then DS subjects with moderate mental retardation should show mild dendritic abnormalities; likewise, if dendritic abnormalities are a sign of global cognitive dysfunction, they should be observed in many other syndromes associated with mental retardation, and dendritic alterations should parallel defects in neuronal maturation and/or decline in cognition. Moreover, these alterations may depend on different cellular mechanisms so that in DS, neurons may not achieve the structural complexity observed in normal children, or alternatively they may undergo greater dendritic retraction during maturation. Good candidate genes exist on chromosome 21, whose altered function could account for both possibilities (see the following).

\subsection{How do dendritic arbourisations develop in Down syndrome brains?}

It has been argued that DS persons start their lives with an apparently normal neuronal architecture that progressively degenerates. Thus, normal or even increased branching in the DS foetus and newborn contrasts with reduced dendrites and degenerative changes in older children with DS. Becker et al. (1986) showed that in infants with DS younger than 6 months, dendritic branching and length in both apical and basilar dendrites were greater than in normal infants. During the peak period of dendritic growth and differentiation, quantitative analysis of dendrites in layer IIIc pyramidal neurons of prefrontal cortex (prospective area 9) of the brains of 2.5-month-old infants revealed no significant differences in dendritic differentiation between euploid and DS cases (Vuksic et al., 2002). In contrast, basilar dendrites of cortical pyramidal neurons are shorter than normal in DS subjects older than 4 months (Takashima et al., 1981). These findings suggest that children with DS begin their lives with morphologically normal layer III pyramidal neurons and that pathologic changes in key prefrontal input-output neuronal elements occur after 2.5 months of postnatal age. Subsequent to this age, there is a steady decrease so that in subjects with DS older than 2 years, these parameters are reduced relative to controls especially in apical dendrites (Becker et al., 1986).

In adults with DS, cross-sectional studies demonstrate marked reductions in dendritic branching and length, and in spine density (Takashima et al., 1989; Becker et al., 1991). Degenerative neuronal changes are also associated with dendritic abnormalities. Two other reports on pyramidal neurons in parietal cortex (Schulz and Scholz, 1992) and on non-pyramidal neurons in motor cortex (Prinz et al., 1997) support these findings. In cases of aged DS brains that do not show Alzheimer disease (AD)-like pathology, the number of spines in the middle and distal segments of apical dendrites of pyramidal neurons in cingulate cortex and in hippocampus are reduced; these changes are more severe in CA1 of those DS cases with AD (Suetsugu and Mehraein, 1980; Ferrer and Guillotta, 1990).

Reductions in the size and dendritic length of pyramidal cells also affect the total number of spines (Fig. 1). Dendritic spines are thin protrusions emerging from dendrites that are the sites of most excitatory synapses in the cerebral cortex. Spines are believed to increase the connectivity of neurons, to provide chemical compartmentalisation for calcium and proteins, and to participate in neural computation (Sorra and Harris, 2000). Recent studies show that dynamic changes in the structure and shape of spines are important for synaptic function (Harris, 1999; Yuste and Bonhoeffer, 2001). Since each spine receives at least one excitatory glutamatergic synapse (reviewed in DeFelipe and Fariñas, 1992; Elston and DeFelipe, 2002), decreases in spine density and number may impair the ability of pyramidal neurons to integrate inputs, and reveal an impaired activity-dependent neural plasticity. The size and branching pattern in the dendritic arbours of pyramidal neurons relate to a number of physiological and biochemical properties of these cells including (1) compartmentalisation of processing of cortical neurons, and (2) synaptic plasticity, a process that refers to the changes in the strength of synaptic function, and includes both short-term changes in the strength or efficacy of neurotransmission as well as longer term changes in the structure and number of synapses (for a review see Elston et al., 2001). Thus, changes in the number of spines in the dendritic arbours of neurons may influence both cellular and systems cortical function (see Elston and DeFelipe, 2002; Elston, 2003b; Jacobs and Scheibel, 2002, for reviews).

Dendritic spines are heterogeneous with regard to their structure, stability and function (see Kasai et al., 2003; Benavides-Piccione et al., 2004). Spines with large heads are stable, express large numbers of AMPA-type glutamate receptors, and contribute to strong synaptic connections. In contrast, spines with small heads are motile and unstable and contribute to weak or silent synaptic connections. These structure-stability-function relationships suggest that large and small spines are 'memory spines' and 'learning spines', respectively (Kasai et al., 2003). Glutamate receptors turnover rapidly, indicating that spine structure and the underlying organisation of the actin cytoskeleton are likely major determinants of fast synaptic transmission and provide a physical basis for memory in cortical neuronal networks. Interestingly, initial studies of infants with DS demonstrated that spines are sparse, small and had short stalks intermingled with unusually long spines in motor cortex (Marin-Padilla, 1972, 1976; Purpura, 1974). The decreased density and long and tortuous profile of spines from DS brains are typical features of spine dysgenesis (Marin-Padilla, 1972). In DS, spine dysgenesis is associated with dendritic vacuolisation and neuronal necrosis (Marin-Padilla, 1976). Therefore, dendritic spine dysgenesis in DS may indicate an early postnatal degenerative process. Takashima et al. (1981) also 


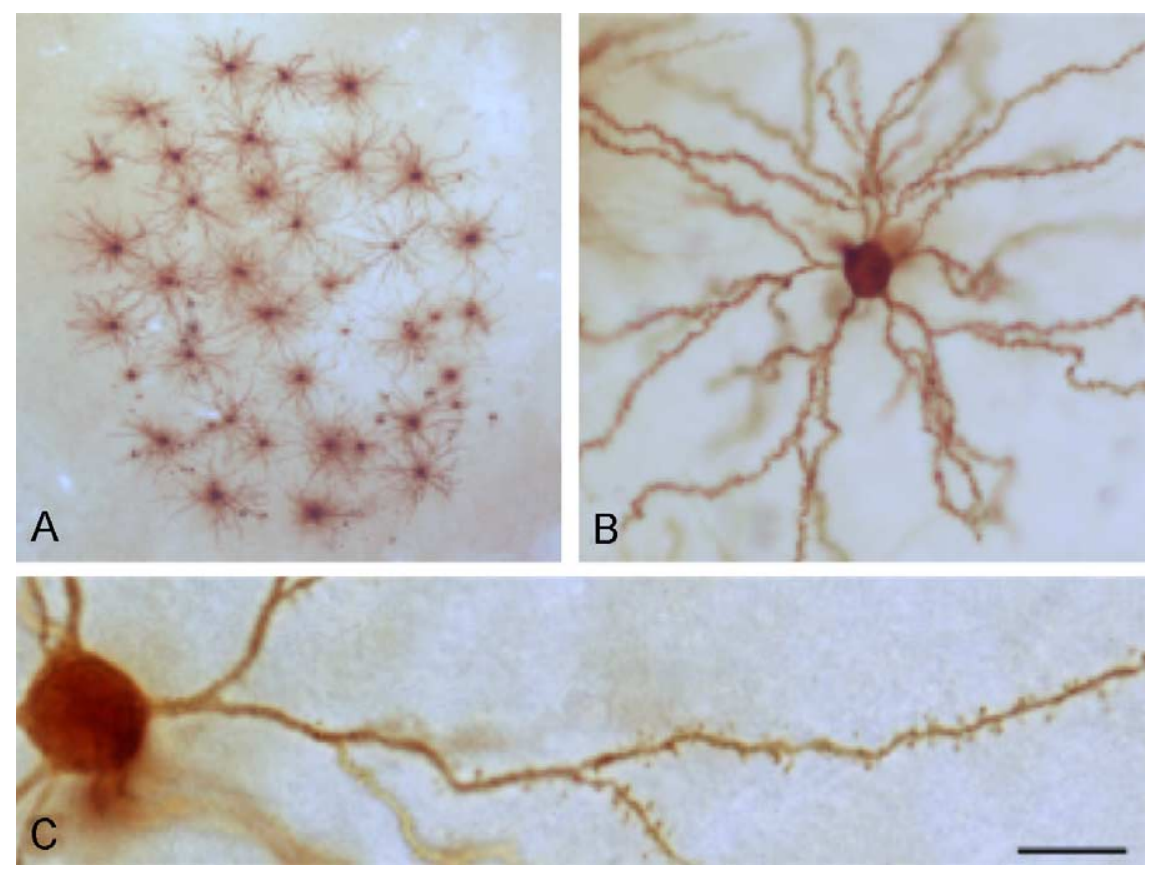

Fig. 1. (A) Low-power photomicrograph of layer III pyramidal cells in a $150-\mu \mathrm{m}$ thick slice taken from the frontal cortex of a wild type mouse that were injected with Lucifer Yellow and processed for a light-stable diaminobenzidine reaction product. (B) Higher magnification showing layer III pyramidal cells of the frontal cortex. (C) High power photo of a horizontally projecting dendrite to illustrate the density and distribution of individual dendritic spines along its length. Note the clear detail of individual dendritic spines. Scale bar: $400 \mu \mathrm{m}$ in (A), $60 \mu \mathrm{m}$ in (B), and $10 \mu \mathrm{m}$ in (C).

raised this possibility in one of the largest studies with respect to sample size that analysed neurons of the visual cortex in foetuses, neonates and infants with DS.

In view of these reports it is likely that the dendritic alterations in DS are the result of deficits in neurodevelopment. Dendritic development is a sequential process in which generation, elongation, and retraction of dendritic branches and spines are the result of the interactions between intrinsic genetic programs and external modulators (e.g., neurotransmitters) (see Kaufmann, 1999; Weitzdoerfer et al., 2001). Dendritic growth initially follows genetic dictates but later becomes modified by levels and patterns of activity (Bartlett and Banker, 1984) in both developing (Kossel et al., 1995; Segal, 1995) and mature systems in response to numerous manipulations, including denervation (Parnavelas et al., 1974), long-term potentiation (LTP) (Buchs and Muller, 1996; Sorra and Harris, 1998), and environmental stimulation (Comery et al., 1996; Jones et al., 1997). With each developmental stage, the expression of a set of dendritic proteins (Petit et al., 1988; Kaufmann et al., 1997), neurotransmitters and growth factors that influence the progression of dendritic development changes. Spines are very dynamic structures; their size, shape and number change throughout life. During development, dendritic protrusions start out as filopodia, which search out contacts with synaptic terminals and then mature into adult spines (Ziv and Smith, 1996). In adults, modulation of the number and shape of spines is associated with synaptic plasticity (Engert and Bonhoeffer, 1999; Maletic-Savatic et al., 1999; Lendvai et al., 2000; Toni et al., 1999) and learning (Comery et al., 1996). Spine abnormalities and changes in the numbers of spines in the dendritic arbours of neurons are commonly reported in neurological disorders such as mental retardation (Purpura, 1974; Geinisman et al., 1992; Dierssen et al., 2003). In DS, pyramidal neurons are morphologically normal at birth, but the number of dendrites and spines decrease steadily in postnatal life. Thus, the genetic defect associated with dendritic disturbances in DS may disrupt signalling pathways and/or modulators of dendritic development (Table 1, see also Section 1.2).

Changes in synaptic function and remodelling of synaptic networks induced by specific patterns of activity are believed to represent key mechanisms for information processing (Stepanyants et al., 2002). Thus, the identification and functional analyses of the gene products involved in DS are critical not only for a better understanding of the causes of mental retardation but also for identifying the cellular and molecular mechanisms contributing to cognitive function.

\subsection{Genetic control of dendritic maturation: what is wrong in Down syndrome?}

Dendritic alterations in DS may be the consequence of higher levels of proteins coded for by three copies of genes on human chromosome 21 (Table 1). Specific genetic loci, especially those in the DS critical region (DSCR), are primary candidates for regulating the abnormal development and maturation of the DS brain (Delabar et al., 1993; Shapiro, 1999). However, genes located on other chromosomes are also involved. The enormous amount of new 
Table 1

HSA21 genes involved in brain development and synaptic plasticity

SIM2 (single-minded homolog 2)

DYRK1A (dual-specificity tyrosine-(Y)-phosphorylation kinase)

GART (phosphoribosylglycinamide formyltransferase)

PCP4 (Purkinje cell protein 4)

DSCAM (Down syndrome cell adhesion molecule)

GRIK1 (glutamate receptor)

APP (amyloid beta (A4) precursor)

S100B (neural) (S100 calcium binding protein beta)

SOD1 (superoxide dismutase 1)

DSCR1 (Down syndrome critical region 1)

ITSN (intersectin)
Synchronized cell division and establishment of (Drosophila) proper cell lineage Expressed during neuroblast proliferation and believed to regulate of

cell-cycle kinetics. Possible role in neuritogenesis and neural plasticity Expressed during prenatal development of the cerebellum

Expressed exclusively in the brain most abundantly in the cerebellum

Role in axonal outgrowth

Expressed in pyramidal cells of the cortex in fetal and early postnatal life and in adult

Involved in plasticity, neurite outgrowth, and Alzheimer disease

Stimulates glial proliferation

Role in apoptosis in fetal DS neural cultures

Role in LTP/LTD

Role in endocytosis molecular and biological data that has developed for human chromosome 21 as a result of the human genome initiative (Hattori et al., 2000a,b) has sped up the understanding of the molecular and cellular basis of mental retardation, and will have an immediate impact on the study of the genetic aspects of DS by providing a comprehensive catalogue of the genes on human chromosome 21 . The gene content of chromosome 21 is now estimated to be 329, including 165 experimentally confirmed genes, 150 gene models based on expressed sequence tag databases and 14 computer predictions (see http://www-eri.uchsc.edu). Several anonymous loci for monogenic disorders and predispositions for common complex disorders have also been mapped to human chromosome 21. However, the functions of most of these genes remain largely unknown, as does their contribution, if any, to DS. The phenotypic consequences of increased gene dosage depend, in part, on the biological function of the gene product itself (e.g., enzyme, structural protein, transcription factor, intracellular signalling molecule, cell surface marker, receptor subunit, etc.). To date, only a few human chromosome 21 encoded genes have been used to make transgenic mice (see Dierssen et al., 1999, 2001, 2003; Pritchard and Kola, 1999 for reviews).

The selection of candidate genes is based on their location in the chromosomal region that is considered critical for the development of the syndrome, the previous knowledge of the functions of the proteins that they encode, or their spatio-temporal pattern of expression. The recent creation of a high-resolution expression 'atlas' of human chromosome 21 is facilitating the understanding of gene function and of the pathogenetic mechanisms in Down syndrome (Gitton et al., 2002; Reymond et al., 2002). The spatial and temporal expression patterns must be linked to structural and physiological changes, information that will shed light on the roles of individual genes in specific developmental pathways.

Multiple molecular cascades are likely to be involved in normal dendritic and spine maturation (see Elston and DeFelipe, 2002; Harris, 1999; Horner, 1993; Shepherd, 1996 for reviews). Here we focus on some of what we consider to be the most salient molecular mechanisms that may be altered in DS individuals, resulting in specific DS associated neuropathology. DYRK1A, is a serin-threonin kinase located on HSA21, has been reported to influence neurogenesis and dendritic development. Yang et al. (2001) showed that overexpression of a kinase-deficient form of $D Y R K 1 A$ attenuates the neurite outgrowth induced by a neurogenic factor in immortalized hippocampal cells. In addition, the expression pattern of DyrklA mRNA and protein at early embryonic ages in mice suggests that it participates in the transition of neuroepithelial cells from proliferating to neurogenic divisions (Hammerle et al., 2002). Dyrk1A also regulates the development of dendritic trees of neurones and modulates the activity of the c-AMP response elementbinding protein (CREB), which participates in signal transduction pathways involved in synaptic plasticity and neuronal differentiation (Hammerle et al., 2003). Finally, DYRK kinases may modulate dendrite development by regulating vesicle trafficking which is dependent on Dynamin (DYN1), a GTPase putative substrate of DYRK1A, that plays a fundamental role in synaptic vesicle recycling, clathrin-mediated endocytosis, intracellular membrane trafficking (see Torre et al., 1994 for a review) and neurite outgrowth (Chen-Hwang et al., 2002; Kim et al., 1997). DYRK1A is transported through the growing dendritic tree where it co-localizes with DYN1 (Hammerle et al., 2003). Taken together these data suggest a relevant function for Dyrk1A during neuronal development, related to proliferation and differentiation. Interestingly, reduced Dyrk1A dosage in mice leads to a decrease in brain size, with no obvious alterations in the lamination and anatomy of the cerebral cortex (Fotaki et al., 2002). In DyrklA haploinsufficient mice, neuropil size is decreased in some brain areas. In particular, pyramidal cells in Dyrk1A+/- layer III are considerably smaller, less branched and less spinous than those in wild type animals, suggesting that Dyrk1A is involved in the determination of the pyramidal cell phenotype and circuit structure (Benavides-Piccione et al., submitted).

Down syndrome cell adhesion molecule (DSCAM) is overexpressed in DS brains. The mechanism by which DSCAM is involved in the pathogenesis of mental 
retardation is by its inhibitory action on synaptogenesis and neurite outgrowth. A lethal mutation in the Drosophila Dscam specifically perturbs segregation of axonal branches (Wang et al., 2002). How does the mutation differ from excess expression of this protein? Axon bifurcation is essential for efficient innervation of multiple targets and results in the formation and divergent segregation of the sister branches.

Amyloid deposition in the form of the $A \beta$ peptide is detected as early as at 21 gestational weeks in DS (Teller et al., 1996), which coincides with normal initial cortical dendritic growth (Huttenlocher, 1990). Inflammatory responses associated with $A \beta$ deposition in senile plaques in AD include production of cytokines (Dickson, 1997), which may operate as negative modulators of dendritic growth and maintenance in DS.

Finally, dendritic spines are extremely motile, providing a structural mechanism for synaptic plasticity (Crick, 1982). As the major cytoskeletal components in dendritic spines, actin filaments provide the basic structural scaffolding of spines (Hayashi et al., 1996; Penzes et al., 2003) and are likely responsible for the changes in the shape of spines. Among actin-regulatory components of spines, drebrin is co-localized with actin filaments at dendritic spines in high-density long-term primary cultures of rat cerebral cortex neurons. Drebrin, an actin-binding protein, is thought to regulate assembly and disassembly of actin filaments (Asada et al., 1994), thereby changing the shape of spines. In fact, when the actinbinding domain of drebrin is deleted, the protein distributes in both spines and dendritic shafts, indicating that the selective accumulation of drebrin in the spines requires its actin-binding activity (Hayashi and Shirao, 1999). In the early second trimester, levels of drebrin and the synaptosomal associated proteins alpha SNAP and SNAP 25 are lower in DS brains (Shim and Lubec, 2002). Thus, spine motility and plasticity may be affected in DS brains. Other genes that may be involved in central nervous system development or neural functions related to synaptic plasticity are listed in Table 1.

\section{The neural phenotype in animal models for Down syndrome: what do we know?}

A better understanding of DS neuronal networks will enhance the understanding of cognitive processes, and to achieve this goal animal models have enormous potential to elucidate mental retardation mechanisms that may be acting in humans. Studies with the various trisomy mouse models at different developmental stages can recreate certain conditions that result in abnormal learning capabilities in DS. Experimental models for human disease have greatly advanced our knowledge of basic brain mechanisms, psychiatric conditions and neurological diseases. The use of transgenic techniques to model human disease has led to major advances in our understanding of pathogenic mechanisms, but has also highlighted the limitations of conventional transgenic methodology for the production of accurate animal models, and the difficulties associated with modelling human pathophysiology in mice (Gerlai, 1996; Crawley and Paylor, 1997; Rogers et al., 1997). We have to bear in mind the limitations of conventional transgenic methodology: the presence of compensatory processes (upor downregulation of gene products) and resulting secondary phenotypical changes, the fact that null-mutant organism might not only lack the product of a single gene but might also possess a number of developmental, physiological, or even behavioural processes that have been altered to compensate for the effect of the null mutation, and the presence of an array of complex phenotypical changes that might not be directly related to the function of the gene of interest.

The varied approaches used to study the consequences of increased gene dosage in DS and to investigate phenotype/ genotype relationships of HSA21 genes in mice (see Cairns, 2001; Galdzicki and Siarey, 2003 for review) are: (1) transgenic animals overexpressing single or combinations of genes, (2) transgenic mice with large foreign DNA pieces introduced on yeast artificial chromosomes (YACs) or bacterial artificial chromosomes into mice (Smith et al., 1995, 1997), (3) mouse models that carry all or part of MMU16, which has regions of conserved homology with HSA21 and (4) chimaeric mice that carry a fragment of human chromosome 21 (Tomizuca et al., 1997).

Single gene transgenesis has been used as a tool to understand the molecular basis of DS. Although overexpressing a single gene will not be a model of DS, the value of single gene transgenesis is to identify genes related to specific pathophysiological features. Studying transgenic mice that overexpress single genes, either with their own genomic regions for gene regulation and expression, or with heterologous promoter sequences that drive the expression of the genes in specific tissues, allows the determination of the contribution of each gene to the phenotype.

The interest in trisomic models lies in modelling and characterizing DS (or a part of it) and in testing therapeutic strategies. Trisomy models have the advantage in that they overexpress orthologues of multiple genes located on HSA21, permitting the study of how multiple genes interact to control each other at the level of transcription. Orthologous genes are frequently linked in similarly conserved chromosomal segments in the mouse and human genomes (Mouse Genome Database: http://www.informatics.jax.org). For this reason aneuploidy for regions of the mouse genome that are conserved on human chromosomes allows for the study of the effects of over (or under) expression of multiple genes. HSA21 shows conserved syntenies to mouse chromosomes (MMU) 16, 17 and 10 (Hattori et al., 2000a,b). Comparative mapping between mice and humans shows that HSA21 shares a large region of genetic homology with MMU16. Based on this rationale, 
mice trisomic for MMU16 has been extensively used as a model for DS. The first mice used had three copies of the complete MMU16 (Ts16 mice). Ts16 mice exhibit some characteristics of DS (Miyabara et al., 1984; Gearhart et al., 1986). However, Ts 16 mice die in utero precluding the study of many of the major features that occur postnatally (e.g., mental retardation, Alzheimer's disease neuropathology). In addition, only 129 of the 731 genes on MMU16 correspond to HSA21, and thus Ts16 mice are not trisomic for some HSA21 genes and have three copies of other genes that are not implicated in the pathogenesis of DS. In spite of all these shortcomings, Ts16 mice do model some of the characteristic features of DS. These features include: (1) cardiac malformations, which are associated with the Down syndrome critical region 1 (DSCR1) gene, encoding a regulatory protein in the calcineurin/NFAT signal transduction pathway (Lange et al., 2004), (2) craniofacial and ocular malformations including a reduction of periorbital connective tissue and micro-ophtalmia (Oster-Granite, 1986) and alterations in the development of the cerebellum, hippocampus and cortical plate (Grausz et al., 1991). The overall reduction in cortical neurons in TS16 is thought to arise from abnormalities in neurogenesis, a failure of brainderived neurotrophic factor-dependent neuron survival and increased caspase-dependent apoptosis (Haydar et al., 1996, 2000; Bambrick and Krueger, 1999; Dorsey et al., 2002). Mouse Ts16 hippocampal neurons demonstrate slowed depolarisation of the AP, reflecting a reduced TTX-sensitive voltage-dependent $\mathrm{Na}^{+}$current and a reduced density of $\mathrm{Na}^{+}$ channels. The dihydropyridine-sensitive, voltage-dependent $\mathrm{Ca}^{2+}$ current is increased, reflecting an increased density of L-type $\mathrm{Ca}^{2+}$ channels. Abnormal $\mathrm{Na}^{+}$and $\mathrm{Ca}^{2+}$ channel densities are not due to reduced transcription of the main channel subunits and thus likely reflect post-translational defects. The abnormalities in Ts 16 hippocampal neurons are opposite in direction to abnormalities in Ts 16 DRG neurons, indicating that there is not a common membrane electrical abnormality in all Ts16 neuronal types. The cell-type differences may reflect, however, a common defect in signal transduction possibly involving channel phosphorylation (see Galdzicki and Siarey, 2003). Selective failure of BDNFdependent survival in cultured hippocampal neurons from the Ts16 mouse has been described. This failure is accompanied by overexpression of a truncated, kinasedeficient isoform of the BDNF receptor tyrosine receptor kinase B (NTRK2). Adenovirus-mediated introduction of exogenous full-length NTRK2 into Ts16 neurons fully restored BDNF-dependent survival, whereas exogenous truncated NTRK2 expression in normal, euploid neurons reproduced the Ts 16 BDNF signalling failure. Thus, the failure of Ts16 neurons to respond to BDNF is caused by dysregulation of NTRK2 isoform expression. Such a neurotrophin signalling defect could contribute to altered late LTP, thus leading to altered structural properties of the dendritic spines with consequences in neural plasticity and possibly in long-term memory storage.
The Ts16 mice present altered corticogenesis (Haydar et al., 1996). Slowed tangential expansion of the neuroepithelium in Ts16 resulted in a reduction of final telencephalic size and is predicted to decrease the number of radial cortical units in the mature brain. In addition, radial growth of the Ts 16 cortex was delayed probably due to a defective cortical neurogenesis, since the number of neocortical founder cells is reduced by $26 \%$ in Ts 16 mice, leading to a reduction in overall cortical size at the end of Ts16 neuronogenesis (Haydar et al., 2000). Thus, altered proliferative characteristics during Ts16 neuronogenesis result in a delay in the generation of neocortical neurons, whereas the founder cell deficit leads to a proportional reduction in the overall number of neurons. Such prenatal perturbations in either the timing of neuron generation or the final number of neurons produced may lead to significant neocortical abnormalities such as those found in DS (Haydar et al., 1996, 2000).

More recently three partial trisomic mice of MMU16 became available (see Gardiner et al., 2003 for review): Ts65Dn mice (Davisson et al., 1990) contain three copies of MMU16 from App to Mxl; Ts1Cje mice have three copies from Sodl to Mxl and Ms1Ts65 (Sago et al., 1998) App to Sod1. The generation by Davisson et al. (1990) of a partial trisomy 16 mouse, the Ts $\left(17^{16}\right)$ 65Dn or Ts65Dn model, that includes most of the MMU16 region homologous to HSA21 (from $A p p$ to $M x l$ ) but which lacks the remaining approximately $40 \%$ of HSA21 genes (Akeson et al., 2001) has lead to a major advance in DS research. Although many genes overexpressed in Ts65Dn are homologous to those included in the DSCR, these mice do not show some of the gross abnormalities frequently observed in DS, such as cardiac valvular congenital abnormalities (Montero et al., 1996). However, Ts65Dn mice exhibit analogous effects on craniofacial structures and cognitive deficits (Escorihuela et al., 1995, 1998; Richtsmeier et al., 2000; Holtzman et al., 1996; Hyde and Crnic, 2002; Hunter et al., 2003; Wenger et al., 2004). In terms of behaviour, the Ts65Dn mice show deficits in reference and working memory that correlate with frontal cortex BDNF levels (Bimonte-Nelson et al., 2003), hyperactivity, reduced attention levels (Escorihuela et al., 1995, 1998; Reeves et al., 1995; Coussons-Read and Crnic, 1996; Holtzman et al., 1996; Hyde et al., 2001), and reduced responsiveness to nociceptive stimuli (Martínez-Cué et al., 1999). Although brain size and histology appear normal in Ts65Dn mice, significant alterations have been reported; high-resolution magnetic resonance imaging and histological analysis reveal neuroanatomical parallels between DS and Ts65Dn cerebellum (Baxter et al., 2000). Cerebellar volume is decreased in Ts65Dn mice due to reductions in both the internal granule layer and the molecular layer. Granule cell number also is decreased. The cerebellar dysmorphology in the Ts65Dn mouse parallels that of DS individuals, and may be related to the global disruption of the cerebellar transcriptome (Saran et al., 2003). In addition, stereological morphometric studies demonstrate minor 


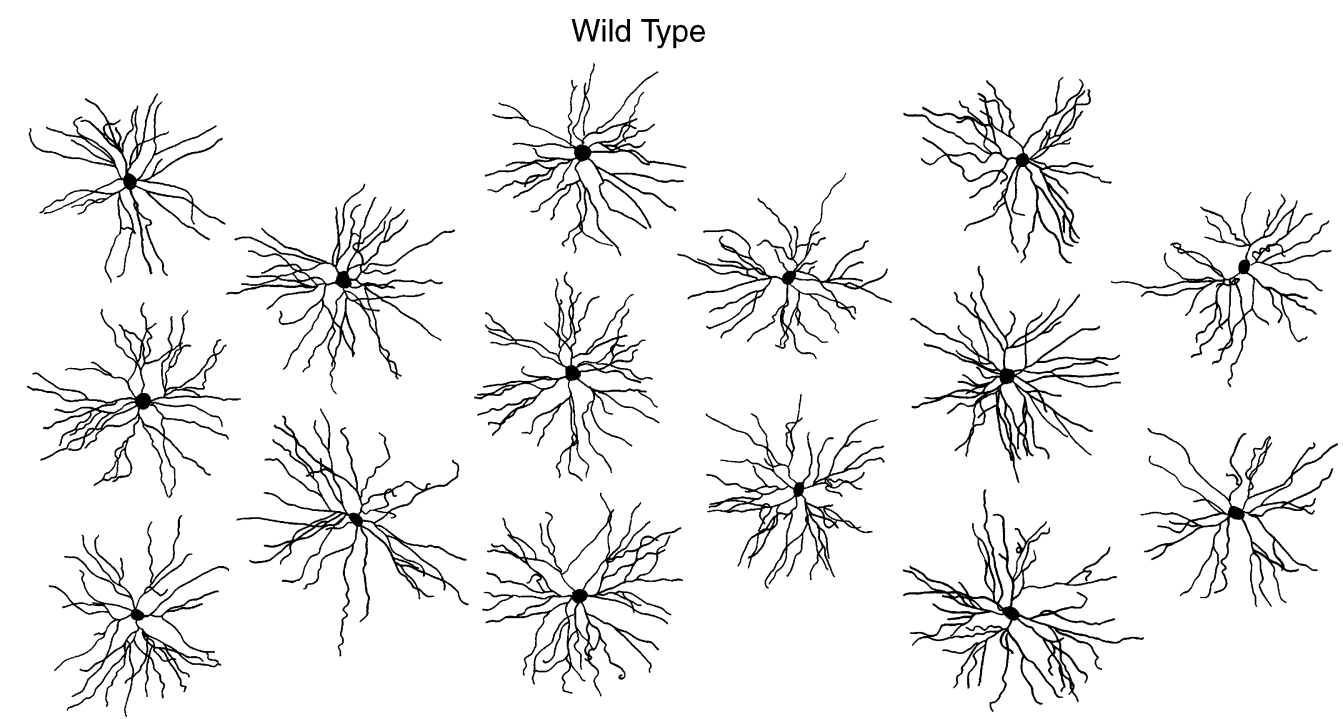

Ts65Dn

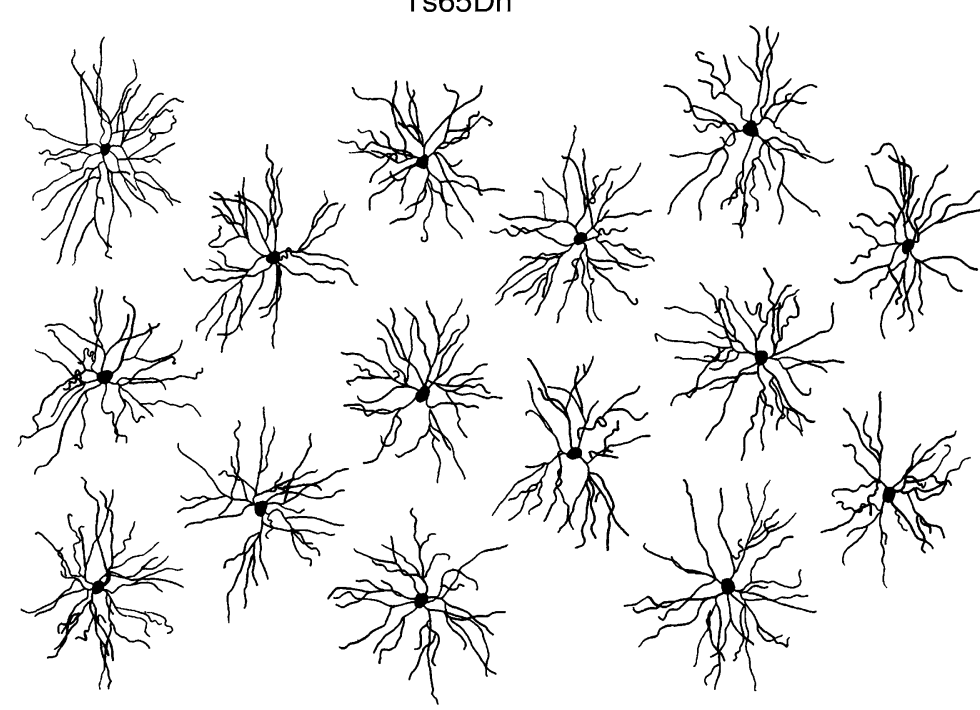

Fig. 2. Camera lucida drawings of layer III pyramidal neurons, as seen in the plane of section parallel to the cortical surface, sampled from wild type and Ts65 $\mathrm{Dn}^{+-}$mice. Illustrated cells have basal dendritic arbours that approximated the average size in each of the groups. Scale bar $=150 \mu \mathrm{m}$.

irregularities in selected regions of the hippocampus of Ts65Dn mice, including reductions in the volume of CA2 and in neuronal density in the dentate gyrus (Insausti et al., 1998).

Of particular interest is the structure of pyramidal cells, the most ubiquitous neuron in the neocortex. Using intracellular injections with Lucifer Yellow to visualize the whole basal dendritic tree, we find that pyramidal cells are smaller, less branched and 24\% less spinous in Ts65Dn mice than those in controls (Fig. 2). These effects on pyramidal cell structure parallel those obtained in humans (see Section 2). The similarity of the structural changes in the Ts65Dn mice to those in DS, indicate that this model will provide a means by which to study brain pathology in DS not possible in humans (see Section 2). More specifically, the Ts65Dn mouse provides a vehicle in which to study the microanatomical substrate of mental retardation in DS, and develop new treatment strategies.

Our group has combined dendritic labelling and synapse analysis in Ts65Dn mice. At old ages, the temporal cortex of Ts65Dn mice has a significantly lower number $(30 \%)$ of asymmetric (presumptive excitatory) synapses while the number of symmetric (presumptive inhibitory) synapses is not different than controls (Kurt et al., 2000). However, the mean synaptic apposition lengths of both asymmetric and symmetric synapses were significantly larger in Ts65Dn mice (15 and $11 \%$, respectively), suggesting that excitatory synapses are preferentially affected in Ts65Dn mice and that there is an attempt to compensate for the deficit of asymmetric synapses by increasing the contact zone area of existing synapses. Neurochemical studies have revealed abnormal patterns in signalling pathways involved in 
activity-dependent synaptic stabilisation and dendrite growth. Adenyl cyclase and phospholipase $\mathrm{C}$ signalling pathways are also severely disturbed in the brain of Ts65Dn mice and patients with DS (Dierssen et al., 1996, 1997; Ruiz de Azua et al., 2001). These alterations may lead to functional abnormalities in the central nervous system since both basal and stimulated production of cyclic AMP (cAMP) are reduced in Ts65Dn mice.

In addition, studies investigating alterations of neurotransmitters, synaptic ultrastructure, and long-term potentiation demonstrate severe deficits in the limbic system of Ts65Dn mice (Siarey et al., 1997). Behavioural studies confirm deficiencies observed at a molecular level, showing that Ts65Dn mice perform poorly on tasks requiring spatial memory, including the Morris maze, the land version of the radial-arm maze (RAM), and context discrimination tasks.

The results of studies of cultured neurons from human foetuses with DS and from foetuses of animal models for DS suggest that the malfunctioning of brain circuits in the DS brain may arise from abnormal neuronal electrical and biochemical properties, since long-term memory storage depends on morphological and biochemical changes associated with experience-dependent plasticity of neuronal synapses. Changes in spine number and morphology reflect mechanisms for converting transient changes in synaptic activity into long-lasting memory. In Ts65Dn mice, abnormalities in the duration of the action potential and its rates of depolarisation and repolarisation, altered kinetics of active $\mathrm{Na}^{+}, \mathrm{Ca}^{2+}$ and $\mathrm{K}^{+}$currents, and altered membrane densities of $\mathrm{Na}^{+}$and $\mathrm{Ca}^{2+}$ channels have been observed (see Galdzicki and Siarey, 2003 for review). Furthermore, electrophysiological studies of the CA1 region of the hippocampus from the adult Ts65Dn mouse show synaptic plasticity changes that lead to abnormalities in LTP and LTD, models of learning and memory (Siarey et al., 1999; Galdzicki and Siarey, 2003).

Ts1Cje is another partial trisomy 16 mouse model for Down syndrome that exhibits learning and behavioural abnormalities (Sago et al., 1998). The Ts1Cje mouse contains a translocated chromosome 16 , and is at dosage imbalance for $67 \%$ of the genes triplicated in Ts65Dn. It has been attempted to assess the phenotypic contribution of the region of difference between Ts65Dn, Ts1Cje, and a new segmental trisomic (Ms1Ts65) for the region of difference (APP to Sod1) by generating these models as littermates and testing them in parallel. Whereas triplication of Sod1 to Mx 1 plays the major role in causing the abnormalities of Ts65Dn in the Morris water maze, imbalance of APP to Sod1 also contributes to the poor performance, so that although the performance of Ts1Cje mice was similar to that of Ts65Dn mice, Ts65Dn was more severely affected in the reverse probe tests. By contrast, the deficits of Ms1Ts65 mice were significantly less severe than those of Ts65Dn (Sago et al., 2000). However, although this first report indicated a dosage-imbalance effect in learning and memory, subse- quent work on other phenotypes gave rise to contradictory results. Trisomic mice have cerebellar pathology with direct parallels to DS. When studying the cerebellar phenotypes in detail, by comparing the three available trisomic models, cerebellar volume was significantly affected to the same degree in Ts1Cje and Ts65Dn, despite that Ts1Cje has fewer triplicated genes. However, dosage imbalance in Ts1Cje had little effect on granule cell and Purkinje cell density. Several mice with dosage imbalance for the segment of the Ts65Dn chromosome not triplicated in Ts1Cje had phenotypes that contrasted with those in Ts1Cje (Olson et al., 2004). These observations point to specific gene action in DS more than a general dosage-imbalance effect.

\section{Pharmacological and non-pharmacological strategies targeting cognitive functions treatments: can we change Down syndrome brains?}

\subsection{Drugs to improve cognition}

Over the years a wide range of therapies to improve cognition in persons with DS have been studied. At present, there is no proven pharmacological treatment for the cognitive or language impairments in DS. Different strategies for the treatment of cognitive deficits in DS have been employed. Dietary supplements such as vitamins and minerals have been proposed to increase the intelligence coefficient in subjects with DS. These approaches are based on the premise that a biochemical imbalance exists in DS. However, recent reviews clearly show no effectiveness of vitamin or mineral supplement in any of the included trials (Salman, 2002; Roizen and Patterson, 2003). Given what is now known regarding the critical periods for synaptic development and the organisation of large-scale neuronal circuits in the developing cerebral cortex, it appears that there may exist a window of opportunity during which specifically targeted, pharmacologic intervention could exert a significantly favourable biologic effect during development. Pharmacologic agents that increase the brain's responsiveness to activity-dependent plasticity may be of particular therapeutic benefit to children with some forms of mental retardation. Currently available medications have targeted cholinergic neurotransmission and to a lesser degree glutamatergic neurotransmission, both of which play important roles in learning, memory, and developmental organisation of the brain.

Enhancement of electrochemical signalling in the brain is based on chemical facilitation of existing synaptic function and is considered to be of short-term benefit. Current pharmacologic strategies, including nootropic drugs such piracetam, a cyclic derivative of gamma amino butyric acid (GABA), are claimed to improve the efficiency of higher order functions in the brain that are involved in cognitive processes such as learning and memory. In addition, based on studies in animals demonstrating synergistic effects of 
combined piracetam/choline treatment, this combination treatment has been recommended for DS. However, the first formal assessment of the efficacy of piracetam in DS has not been positive (Lobaugh et al., 2001). Results from a recently reported double-blind, placebo-controlled, crossover study of the efficacy of piracetam for increasing cognitive functioning in DS have shown not only that piracetam treatment did not enhance cognitive performance but also that it was associated with a number of adverse effects in children with DS. More recently, the efficacy of piracetam treatment has been explored in Ts65Dn mice, and after cognitive evaluation, the data reveal no support for the treatment of individuals with DS (Moran et al., 2002).

The "cholinergic hypothesis" of memory dysfunction has done much to focus research efforts on cholinergic strategies for the enhancement of learning and memory. Medications that affect cholinergic neurotransmission include acetylcholine precursors, acetylcholinesterase inhibitors, and muscarinic agonists. DS is associated with early dementia with similarities in pathology and biochemistry to $\mathrm{AD}$, providing a rationale for the use of cholinesterase inhibitors (see Gustavson and Cummings, 2003). There is a known loss of cholinergic neurons providing input to limbic structures and cortex in both AD and DS. There is accumulation of abnormal beta-amyloid in both disorders, which presumably causes neuronal death and hence a presynaptic deficit. Cholinesterase inhibitors can be predicted to be helpful in this disorder and are beneficial for some of the cognitive and functional deficits associated with AD. However, despite considerable theoretical reasons to suggest patients with DS, especially those with concurrent dementia, could derive benefit from cholinesterase inhibitor therapy, there are currently few studies reported in the literature from which to draw a conclusion. Some authors claim improvement in socialisation subscale and adaptive behaviour composite score (Kishnani et al., 1999) in patients with DS with or without dementia (Lott et al., 2002; Prasher et al., 2002). Others report no clinical benefit and frequent adverse effects (Cipriani et al., 2002; Hemingway-Eltomey and Lerner, 1999). Recently, adults with DS were treated with donepezil as a therapy for language deficits. The results indicate an improvement in expressive language performance in patients with DS (Heller et al., 2003).

Tests of various hormone therapies, including thyroid, steroid and growth hormone have yielded only poor results. However, a recent study carried out in Ts65Dn mice indicates that estrogen treatment can restore cognition and cholinergic phenotype. The authors show that female mice (11-15 months) that received a subcutaneous estrogenic pellet improved learning of a T-maze task and normalized behaviour in reversal learning of the task, a measure of cognitive flexibility (Granholm et al., 2000). Moreover, the total number of cholinergic neurons in the medial septum, identified by alterations in amyloid precursor protein as well as dendritic and cholinergic markers, increased (Granholm et al., 2002, 2003). The authors suggest that estrogenic treatment might be a viable therapeutic approach for women with DS coupled with dementia.

Drugs targeting the glutamatergic system are among the most novel modalities in treating disorders of memory and learning. These drugs have grown in proportion to advancements in our understanding of the physiologic and pathologic alterations underlying mental retardation.

Animal models of memory formation indicate that synaptic events lead to an intracellular cascade involving calcium fluxes, a variety of protein kinases, and activation of transcription factors and immediate early genes such as cFos, c-Jun and Zif-268 (see Rose, 2002 for review). An important step in this sequence involves the cyclic-AMPresponsive-element-binding protein (CREB), which is implicated in memory formation in both Drosophila and mice. However, the ability of these interventions to enhance human memory through facilitation on synaptic activitydependent events remains speculative at present.

Although gene therapy for DS is probably years down the road, it holds great promise for increasing the specificity of treatments while reducing unnecessary or dangerous side effects. In DS, where overexpression of a number of genes exists, gene therapy approaches will have to focus in reducing gene expression. As we begin to understand the function of specific genes and identify the contribution of individual genes to the overall phenotype, partial gene therapy for specific defects could be a good approach. One of the main caveats for gene therapy is that it requires a technology capable of gene transfer in a wide variety of cells, tissues and whole organs. To date, antisense oligonuceotides or ribozymes were the only available tools for reducing gene expression. Several in vivo studies have shown that antisense oligonucleotides directly delivered to the brain of animals modify behaviour (Zapata et al., 1997; Persico et al., 1998). This finding strongly supports the proposal that reducing gene expression by gene therapy approaches has the potential to treat disorders associated with gene overexpression in the CNS. Although still not optimum, several delivery vectors are available to introduce genes (Somia and Verma, 2000). Highly efficient systems, such as adenovirus, adeno-associated virus and more recently lentivirus, deliver genes into mature neurons both in vivo and in vitro, allowing the design of gene therapies for brain diseases (Costantini et al., 2000). A novel, very powerful gene silencing mechanism, RNA interference (RNAi), recently was discovered. Gene therapy approaches that are being developed that are based on this technology hold great promise for targeting candidate overexpressed genes in DS (McManus and Sharp, 2002; Song et al., 2003).

\subsection{Non-pharmacological strategies}

Early implementation of special education programs leads to improved cognitive abilities in individuals with DS (Connolly et al., 1993; Foreman and Manning, 1986) but the 
cognitive improvements achieved are limited, and temporary. The neural correlates of the temporary effects are unknown. Animals reared in enriched environments outperform conspecifics in learning, memory and visual acuity, suggesting that circuits are modified in order to optimise multiple levels of information processing and storage (Fernandez-Teruel et al., 1997; Prusky et al., 2000). Structural differences in the cerebral cortex are thought to underpin these behavioural improvements. Past studies of the intact brain using Golgi impregnated material correlate changes in dendritic spine morphology with development, enriched environment and aging. The rationale for these studies is that alterations in these conditions would exert major changes in brain structure and function (Rosenzweig et al., 1972; Volkmar and Greenough, 1972; Globus et al., 1973). These studies show that experience correlates with an increase in the spine density, in the complexity of dendritic arbourisation and in the length of cortical dendrites.

Recently, the effect of enriched environment applied to pups for 7 weeks after weaning upon behavioural and cognitive performances was assessed in partially trisomic Ts65Dn mice. Exposure to complex environments modulated behaviour and spatial memory in Ts65Dn and euploid mice (Martinez-Cue et al., 2002). Moreover, the effects on behaviour were sex-specific. Environmental enrichment induced a slight but significant improvement of performance in Ts65Dn females but worsened performance in Ts65Dn male mice in the Morris water maze. These results indicate that gender is a factor that impacts this behavioural intervention (Martinez-Cue et al., 2002).

In our experimental design (Dierssen et al., 2003), euploid, non-trisomic mice exposed to an enriched environment showed increases in dendritic complexity and in the number of spines. These effects could account for the better performance on some of the behavioural tasks. However, environmental enrichment did not alter the spine density or the number of spines in Ts65Dn mice. These results suggest that the molecular pathways that mediate neuronal reinforcement in the early stages of pruning might be affected by the partial trisomy of MMU16, resulting in different behavioural and cognitive abilities. Despite the marked differences in the number of spines found on the dendritic arbours of pyramidal cells in the different experimental groups, the distribution of the spines throughout the arbours remains remarkably similar (Elston and DeFelipe, 2002).

Mechanisms that determine spine morphology remain controversial. In cortex, it has been suggested that processes which lead to shrinkage and elongation of dendritic spines are controlled locally. In contrast, processes leading to the formation of novel spines may extend beyond local biochemical events (Smart and Halpain, 2000) or may be engineered centrally, through messages arriving from the soma, where a global increase in dendritic spine density is seen after a nuclear message (phosphorylation of CREB) (see Segal, 2001 for review).
Recently it has been documented that levels of neurotrophic factors such as BDNF increase in the central nervous system in response to enhanced environmental complexity (Falkenberg et al., 1992; Ickes et al., 2000; Pham et al., 1999; Torasdotter et al., 1998). Levels of BDNF are altered in Ts65Dn mice and in children with DS (Calamandrei et al., 2000). This neurotrophic factor impacts the survival of the basal prosencephalon cholinergic nucleus (Cooper et al., 2001; Delcroix et al., 2004). Other candidate molecules that guide morphological restructuring, synaptogenesis, and synaptic weighing and that control the plastic changes induced by environmental enrichment in the CNS (Rampon et al., 2000) may also be affected in this DS model. Thus, the behavioural consequences of enrichment observed in the Ts65Dn mice may not be entirely the result of the structural reorganisation of the pyramidal cells of the frontal cortex. Since stable long-term changes in spines are involved in the formation of stable memories, it might be argued that the less-stable behavioural effects of environmental enrichment could be dependent on more transient effects on functional synaptic mechanisms.

\section{Conclusions}

This paper addresses the mechanisms that cause mental deficiency in Down syndrome and the enduring question of the relationship between structure and function in the cerebral cortex. DS is associated with several brain abnormalities including altered cortical volume, stratification, dendritic atrophy, cellular differentiation and synaptic dysgenesis during the post-natal period. Some of these changes, such as dendritic alterations are also present in other cognition disorders and have been proposed as the most consistent anatomopathological feature of mental retardation. A better understanding of DS neuronal networks is essential to understand the alterations of cognitive processes, and to achieve this goal animal models have enormous potential to elucidate mental retardation mechanisms that may be acting in humans. Animal models can overcome many of the limitations inherent in studies of human patients, such as rarity of the disease, extremely complex genetic background and logistical and ethical constraints in the design and execution of experiments with human subjects. To date, these models have helped in the clarification of the pathophysiology/pathogenetic mechanism of disease and they will serve the exploration of therapeutic approaches in the near future. Studies with the various animal models of DS at different developmental stages have recreated certain conditions that result in abnormal learning capabilities in DS, and previous work has found abnormalities of cortical volume, lamination, proliferation and connectivity. We propose that some genes are major candidates to explain the dendritic spine functional and structural alteration. These genes will most probably be those who have been proven to produce a dosage-dependent 
phenotype. Changes in levels of expression of these genes may lead to changes in timing and synaptic interaction between neurons during development, which can lead to less than optimal functioning of neural circuitry and signalling at that time and in later life.

\section{Acknowledgments}

This work was supported in part by grants of Jerôme Lejeune Foundation, European Union (QLG1-CT-200200816), CICYT (SAF2001-1231), and DGCYT, Australian National Health and Medical Research Council (GNE), Comunidad Autónoma de Madrid (RB-P, 01/0782/2000), Fundación CIEN.

\section{References}

Akeson, E.C., Lambert, J.P., Narayanswami, S., Gardiner, K., Bechtel, L.J., Davisson, M.T., 2001. Ts65Dn: localization of the translocation breakpoint and trisomic gene content in a mouse model for Down syndrome. Cytogenet. Cell. Genet. 93, 270-276.

Anneren, G., Pueschel, S.M., 1996. Preventive medical care. In: Stratford, B., Gunn, P. (Eds.), New Approaches to Down Syndrome, Casell, London.

Asada, H., Uyemura, K., Shirao, T., 1994. Actin-binding protein, drebrin, accumulates in submembranous regions in parallel with neuronal differentiation. J. Neurosci. Res. 38, 149-159.

Bacon, J.P., Murphey, R.K., 1984. Receptive fields of cricket giant interneurones are related to their dendritic structure. J. Physiol. 352, 601623.

Bambrick, L.L., Krueger, B.K., 1999. Neuronal apoptosis in mouse trisomy 16: mediation by caspases. J. Neurochem. 72, 1769-1772.

Bartlett, W.P., Banker, G.A., 1984. An electron microscopic study of the development of axons and dendrites by hippocampal neurons in culture. Cells which develop without intercellular contacts. J. Neurosci. 4, 1944 1953.

Baxter, L.L., Moran, T.H., Richtsmeier, J.T., Troncoso, J., Reeves, R., 2000. Discovery and genetic localization of Down syndrome cerebellar phenotypes using the Ts65Dn mouse. Hum. Mol. Genet 9, 195-202.

Benavides-Piccione, R., Dierssen, M., Ballesteros-Yáñez, I., Martínez de Lagrán, M., Arbonés, M.L., Fotaki, V., DeFelipe, J.y, Elston, G.N., 2004. Brain size and circuit complexity: a study of the cerebral cortex in Dyrk1A +/- mouse. Neurobiology Disease (submitted).

Benavides-Piccione, R., Dierssen, M., Ballesteros-Yáñez, I., Martínez de Lagrán, M., Arbonés, M., Fotaki, V., Estivill, X., DeFelipe, J., Elston, G.N., submitted. A study of the pyramidal cell phenotype in the Dyrk1A $+/$ - mouse model implicates DYRK1A as a candidate gene for mental retardation in microcephaly cerebral cortex. Neurobiol. Dis.

Becker, L.E., Armstrong, D.L., Chan, F., 1986. Dendritic atrophy in children with Down's syndrome. Ann. Neurol. 20, 520-526.

Becker, L., Mito, T., Takashima, S., Onodera, K., 1991. Growth and development of the brain in Down syndrome. Prog. Clin. Biol. Res. 373, 133-152.

Bimonte-Nelson, H.A., Hunter, C.L., Nelson, M.E., Granholm, A.C., 2003. Frontal cortex BDNF levels correlate with working memory in an animal model of Down syndrome. Behav. Brain Res. 139, 47-57.

Buchs, P.-A., Muller, D., 1996. Induction of long-term potentiation is associated with major ultrastructural changes of activated synapses. Proc. Natl. Acad. Sci. U.S.A. 93, 8040-8045.

Cairns, N.J., 2001. Molecular neuropathology of transgenic mouse models of Down syndrome. J. Neural Transm. Suppl. 61, 289-301.
Calamandrei, G., Alleva, E., Cirulli, F., Queyras, A., Volterra, V., Capirci, O., Vicari, S., Giannotti, A., Turrini, P., Aloe, L., 2000. Serum NGF levels in children and adolescents with either Williams syndrome or Down syndrome. Dev. Med. Child Neurol. 42, 746-750.

Chen-Hwang, M.C., Chen, H.R., Elzinga, M., Hwang, Y.W., 2002. Dynamin is a minibrain kinase/dual specificity Yak1-related kinase 1A substrate. J. Biol. Chem. 277, 17597-17604.

Cipriani, G., Bianchetti, A., Trrabucchi, M., 2002. Donepezil use in the treatment of dementia associated with Down syndrome. Arch. Neurol. 60, 292.

Costantini, L.C., Bakowska, J.C., Breakefield, X.O., Isacson, O., 2000. Gene therapy in the CNS. Gene Ther. 7, 93-109.

Cooper, J.D., Salehi, A., Delcroix, J.D., Howe, C.L., Belichenko, P.V., Chua-Couzens, J., Kilbridge, J.F., Carlson, E.J., Epstein, C.J., Mobley, W.C., 2001. Failed retrograde transport of NGF in a mouse model of Down's syndrome: reversal of cholinergic neurodegenerative phenotypes following NGF infusion. Proc. Natl. Acad. Sci. U.S.A. 98, 1043910444.

Comery, T.A., Stamoudis, C.X., Irwin, S.A., Greenough, W.T., 1996. Increased density of multiple-head dendritic spines on medium-sized spiny neurons of the striatum in rats reared in a complex environment. Neurobiol. Learn. Mem. 66, 93-96.

Connolly, B.H., Morgan, S.B., Russell, F.F., Fulliton, W.L., 1993. A longitudinal study of children with Down syndrome who experienced early intervention programming. Phys. Ther. 73, 170-179.

Coussons-Read, M.E., Crnic, L.S., 1996. Behavioral assessment of the Ts65Dn mouse, a model for Down syndrome: altered behavior in the elevated plus maze and open field. Behav. Genet. 26, 7-13.

Crawley, J., Paylor, R., 1997. A proposed test battery and constellations of specific behavioral paradigms to investigate the behavioral phenotypes of transgenic and knockout mice. Horm. Behav. 31, 197-211.

Crick, F., 1982. Do dendritic spines twitch? Trends Neurosci. 5, 44-46.

Davisson, M.T., Schmidt, C., Akeson, E.C., 1990. Segmental trisomy for murine chromosome 16: a new system for studying Down syndrome. In: Patterson, D., Epstein, C.J. (Eds.), Molecular Genetics of Chromosome 21 and Down syndrome.Wiley-Liss, New York, pp. 263-280.

DeFelipe, J., Fariñas, I., 1992. The pyramidal neuron of the cerebral cortex: Morphological and chemical characteristics of the synaptic inputs. Prog. Neurobiol. 39, 563-607.

Delabar, J.M., Theophile, D., Rahmani, Z., Chettouh, Z., Blouin, J.L., Prieur, M., Noel, B., Sinet, P.M., 1993. Molecular mapping of twenty-four features of Down syndrome on chromosome 21. Eur. J. Hum. Genet. 1, 114-124.

Delcroix, J.D., Valletta, J., Wu, C., Howe, C.L., Lai, C.F., Cooper, J.D., Belichenko, P.V., Salehi, A., Mobley, W.C., 2004. Trafficking the NGF signal: implications for normal and degenerating neurons. Prog. Brain Res. 146, 3-23.

Dickson, D.W., 1997. The pathogenesis of senile plaques. J. Neuropathol. Exp. Neurol. 56, 321-339.

Dierssen, M., Vallina, I.F., Baamonde, C., García-Calatayud, S., Lumbreras, M.A., Flórez, J., 1997. Alterations of central noradrenergic transmission in Ts65Dn mouse, a model for Down syndrome. Brain Res. 749, 238 243.

Dierssen, M., Vallina, I.F., Baamonde, C., Lumbreras, M.A., Martínez-Cué, C., Calatayud, S.G., Flórez, J., 1996. Impaired cyclic AMP production in the hippocampus of a Down syndrome murine model. Dev. Brain Res. 95, 122-124

Dierssen, M., Pritchard, M., Fillat, C., Arbonés, M., Aran, J.M., Flórez, J., Estivill, X., 1999. Modelling Down syndrome in mice. In: Gerlai, R., Crusio, W. (Eds.), Molecular-Genetic Techniques for Brain and Behavior Research, Elsevier.

Dierssen, M., Fillat, C., Crnic, L., Arbones, M., Florez, J., Estivill, X., 2001. Murine models for Down syndrome. Physiol. Behav. 73, 859-871.

Dierssen, M., Benavides-Piccione, R., Martínez-Cué, C., Estivill, X., Flórez, J., Elston, G.N., DeFelipe, J., 2003. Alterations of neocortical pyramidal cell phenotype in the Ts65Dn mouse model of Down 
syndrome: effects of environmental enrichment. Cereb. Cortex 13, 758764.

Dorsey, S.G., Bambrick, L.L., Balice-Gordon, R.J., Krueger, B.K., 2002. Failure of brain-derived neurotrophic factor-dependent neuron survival in mouse trisomy 16. J. Neurosci. 22, 2571-2578.

Elston, G.N., 2003a. Cortex, cognition and the cell: new insights into the pyramidal neuron and prefrontal function. Cereb. Cortex 13, 11241138.

Elston, G.N., 2003b. The pyramidal neuron in occipital, temporal and prefrontal cortex of the owl monkey (Aotus trivirgatus): regional specialization in cell structure. Eur. J. Neurosci. 17, 1313-1318.

Elston, G.N., Benavides-Piccione, R., DeFelipe, J., 2001. The pyramidal cell in cognition: a comparative study in human and monkey. J. Neurosci. 21, RC163.

Elston, G.N., DeFelipe, J., 2002. Spine distribution in cortical pyramidal cells: a common organizational principle across species. Prog. Brain Res. 136, 109-133.

Engert, F., Bonhoeffer, T., 1999. Dendritic spine changes associated with hippocampal long-term synaptic plasticity. Nature 399, 66-70.

Escorihuela, R.M., Fernández-Teruel, A., Vallina, I.F., Baamonde, C., Lumbreras, M.A., Dierssen, M., Tobeña, A., Flórez, J., 1995. Behavioral assessment of Ts65Dn mice: a putative DS model. Neurosci. Lett. 199, 143-146.

Escorihuela, R.M., Vallina, I.F., Martínez-Cué, C., Baamonde, C., Dierssen, M., Tobeña, A., Flórez, J., Fernández-Teruel, A., 1998. Impaired shortand long-term memory in Ts65Dn mice, a model for DS. Neurosci. Lett. 247, 171-174.

Falkenberg, T., Mohammed, A.K., Henriksson, B., Persson, H., Winblad, B., Lindefors, N., 1992. Increased expression of brain-derived neurotrophic factor mRNA in rat hippocampus is associated with improved spatial memory and enriched environment. Neurosci. Lett. 138, 153156.

Fernandez-Teruel, A., Escorihuela, R.M., Castellano, B., Gonzalez, B., Tobena, A., 1997. Neonatal handling and environmental enrichment effects on emotionality, novelty/reward seeking, and age related cognitive and hippocampal impairmentes: focus on the Roman rat lines. Behav. Genet. 27, 513-526.

Ferrer, I., Guillotta, F., 1990. Down's syndrome and Alzheimer's disease: dendritic spine counts in the hippocampus. Acta Neuropathol. (Berl.) $79,680-685$.

Flórez, J., 1992. Neurologic abnormalities. In: Pueschel, S.M., Pueschel, J.K., Paul, H. (Eds.), Biomedical Concerns in Persons with Down Syndrome. Brookes Pub. Co, Baltimore, pp. 159-173.

Foreman, P.J., Manning, E., 1986. Paediatric management practices in Down syndrome: a follow-up survey. J. Paediatr. Child Health 29, $27-31$.

Fotaki, V., Dierssen, M., Alcántara, S., Martínez, S., Martí, E., Casas, C., Visa, J., Soriano, E., Estivill, X., Arbonés, M.L., 2002. Dyrk1A haploinsufficiency affects viability and causes developmental delay and abnormal brain morphology in mice. Mol. Cell Biol. 22, 6636-6647.

Friedlander, M.J., Stanford, L.R., Sherman, S.M., 1982. Effects of monocular deprivation on the structure-function relationship of individual neurons in the cat's lateral geniculate nucleus. J. Neurosci. 2, 321-330.

Galdzicki, Z., Siarey, R.J., 2003. Understanding mental retardation in Down's syndrome using trisomy 16 mouse models. Genes Brain Behav. $2,167-178$.

Gardiner, K., Fortna, A., Bechtel, L., Davisson, M.T., 2003. Mouse models of Down syndrome: how useful can they be? Comparison of the gene content of human chromosome 21 with orthologous mouse genomic regions. Gene 318, 137-147.

Gearhart, J.D., Davisson, M.T., Oster-Granite, M.L., 1986. Autosomal aneuploidy in mice: generation and developmental consequences. Brain Res. Bull. 16, 789-801.

Geinisman, Y., de Toledo-Morrell, F., Persina, I.S., Rossi, M., 1992. Agerelated loss of axospinous synapses formed by two afferent systems in the rat dentate gyrus as revealed by the unbiased stereological dissector technique. Hippocampus 2, 437-444.
Gerlai, R., 1996. Gene targetting studies of mammalian behavior: is it the mutation or the background phenotype? Trends Neurosci. 19, 177181.

Gitton, Y., Dahmane, N., Baik, S., Ruiz i Altaba, A., Neidhardt, L., Scholze, M., Herrmann, B.G., Kahlem, P., Benkahla, A., Schrinner, S., Yildirimman, R., Herwig, R., Lehrach, H., Yaspo, M.L., 2002. HSA21 expression map initiative. A gene expression map of human chromosome 21 orthologues in the mouse. Nature 420, 586-590.

Globus, A., Rosenzweig, M.R., Bennett, E.L., Diamond, M.C., 1973. Effects of differential experience on dendritic spine counts in rat cerebral cortex. J. Comp. Physiol. Psychol. 82, 175-181.

Golden, J.A., Hyman, B.T., 1994. Development of the superior temporal neocortex is anomalous in trisomy 21. J. Neuropathol. Exp. Neurol. 53, 513-520.

Granholm, A.-C., Sanders, E., Crnic, L.A., 2000. Loss of cholinergic phenotype in basal forebrain coincides with cognitive decline in a mouse model of Down's syndrome. Exp. Neurol. 161, 647-663.

Granholm, A.E., Ford, K.A., Hyde, L.A., Bimonte, H.A., Hunter, A.L., Nelson, M., Albeck, D., Sanders, L.A., Mufson, E.J., Crnic, L.S., 2002. Estrogen restores cognition and cholinergic phenotype in an animal model of Down syndrome. Physiol. Behav. 77, 371-385.

Granholm, A.C., Sanders, L., Seo, H., Lin, L., Ford, K., Isacson, O., 2003. Estrogen alters amyloid precursor protein as well as dendritic and cholinergic markers in a mouse model of Down syndrome. Hippocampus 13, 905-914.

Grausz, H., Richtsmeier, J.T., Oster-Granite, M.L., 1991. Morphogenesis of the brain and craniofacial complex in trisomy 16 mice. In: Epstein, C.J. (Ed.), The Morphogenesis of Down Syndrome. Wiley-Liss, New York, pp. 169-188.

Gustavson, A.R., Cummings, J.L., 2003. Cholinesterase inhibitors in non-Alzheimer dementias. J. Am. Med. Dir. Assoc. 4 (6 Suppl.), $165-169$.

Hammerle, B., Vera-Samper, E., Speicher, S., Arencibia, R., Martinez, S., Tejedor, F.J., 2002. Mnb/Dyrk1A is transiently expressed and asymmetrically segregated in neural progenitor cells at the transition to neurogenic divisions. Dev. Biol. 246, 259-273.

Hammerle, B., Carnicero, A., Elizalde, C., Ceron, J., Martinez, S., Tejedor, F.J., 2003. Expression patterns and subcellular localization of the Down syndrome candidate protein MNB/DYRK1A suggest a role in late neuronal differentiation. Eur. J. Neurosci. 17, 2277-2286.

Harris, K.M., 1999. Structure, development, and plasticity of dendritic spines. Curr. Opin. Neurobiol. 9, 343-348.

Hassold, T., Jacobs, P., 1984. Trisomy in man. Ann. Rev. Genet. 18, 69-97.

Hattori, M., Fujiyama, A., Taylor, T.D., Watanabe, H., Yada, T., Park, H.S., Toyoda, A., Ishii, K., Totoki, Y., Choi, D.K., Soeda, E., Ohki, M., Takagi, T., Sakaki, Y., Taudien, S., Blechschmidt, K., Polley, A., Menzel, U., Delabar, J., Kumpf, K., Lehmann, R., Patterson, D., Reichwald, K., Rump, A., Schillhabel, M., Schudy, A., 2000a. The DNA sequence of human chromosome 21 . The chromosome 21 mapping and sequencing consortium. Nature 405, 311-319.

Hattori, M., Fujiyama, A., Taylor, T.D., Watanabe, H., Yada, T., Park, H.S., Toyoda, A., Ishii, K., Totoki, Y., Choi, D.K., Groner, Y., Soeda, E., Ohki, M., Takagi, T., Sakaki, Y., Taudien, S., Blechschmidt, K., Polley, A., Menzel, U., Delabar, J., Kumpf, K., Lehmann, R., Patterson, D., Reichwald, K., Rump, A., Schillhabel, M., Schudy, A., Zimmermann, W., Rosenthal, A., Kudoh, J., Schibuya, K., Kawasaki, K., Asakawa, S., Shintani, A., Sasaki, T., Nagamine, K., Mitsuyama, S., Antonarakis, S.E., Minoshima, S., Shimizu, N., Nordsiek, G., Hornischer, K., Brant, P., Scharfe, M., Schon, O., Desario, A., Reichelt, J., Kauer, G., Blocker, H., Ramser, J., Beck, A., Klages, S., Hennig, S., Riesselmann, L., Dagand, E., Haaf, T., Wehrmeyer, S., Borzym, K., Gardiner, K., Nizetic, D., Francis, F., Lehrach, H., Reinhardt, R., Yaspo, M.L., 2000b. Chromosome 21 mapping and sequencing consortium. The DNA sequence of human chromosome 21. Nature 405, 311-319.

Hayashi, K., Shirao, T., 1999. Change in the shape of dendritic spines caused by overexpression of drebrin in cultured cortical neurons. J. Neurosci. 19, 3918-3925. 
Hayashi, K., Ishikawa, R., Ye, L.H., He, X.L., Takata, K., Kohama, K., Shirao, T., 1996. Modulatory role of drebrin on the cytoskeleton within dendritic spines in the rat cerebral cortex. J. Neurosci. 16, 7161-7170.

Haydar, T.F., Blue, M.E., Molliver, M.E., Krueger, B.K., Yarowsky, P.J., 1996. Consequences of trisomy 16 for mouse brain development: corticogenesis in a model of Down syndrome. J. Neurosci. 16, 61756182.

Haydar, T.F., Nowakowsky, R.S., Yarowsky, P.J., Krueger, B.K., 2000. Role of founder cell deficit and delayed neuronogenesis in microcephaly of the trisomy 16 mouse. J. Neurosci. 20, 4156-4164.

Heller, J.H., Spiridigliozzi, G.A., Sullivan, J.A., Doraiswamy, P.M., Krishnan, R.R., Kishnani, P.S., 2003. Donepezil for the treatment of language deficits in adults with down syndrome: a preliminary 24-week open trial. Am. J. Med. Genet. 116B, 111-116.

Hemingway-Eltomey, J.M., Lerner, A.J., 1999. Adverse effects of donepezil in treating Alzheimer's disease associated with Down's syndrome. Am. J. Psychiatry 156, 1470.

Holtzman, D.M., Santucci, D., Kilbridge, J., Chua-Couzens, J., Fontana, D.J., Daniels, S.E., Johnson, R.M., Chen, K., Sun, Y., Carlson, E., Alleva, E., Epstein, C.J., Mobley, W.C., 1996. Developmental abnormalities and age-related neurodegeneration in a mouse model of Down syndrome. Proc. Natl. Acad. Sci. U.S.A. 93, 13333-13338.

Horner, C.H., 1993. Plasticity of the dendritic spine. Prog. Neurobiol. 41, 281-321.

Hunter, C.L., Bimonte, H.A., Granholm, A.C., 2003. Behavioral comparison of 4 and 6 month-old Ts65Dn mice: age-related impairments in working and reference memory. Behav. Brain Res. 138, 121-131.

Huttenlocher, P.R., 1990. Morphometric study of human cerebral cortex development. Neuropsychologia 28, 517-527.

Hyde, L.A., Frisone, D.F., Crnic, L.S., 2001. Ts65Dn mice, a model for Down syndrome, have deficits in context discrimination learning suggesting impaired hippocampal function. Behav. Brain Res. 118, 53-60.

Hyde, L.A., Crnic, L.S., 2002. Reactivity to object and spatial novelty is normal in older Ts65Dn mice that model Down syndrome and Alzheimer's disease. Brain Res. 945, 26-30.

Ickes, B.R., Pham, T.M., Sanders, L.A., Albeck, D.S., Mohammed, A.H., Granholm, A.C., 2000. Long-term environmental enrichment leads to regional increases in neurotrophin levels in rat brain. Exp. Neurol. 164, $45-52$.

Insausti, A.M., Megías, M., Crespo, D., Cruz-Orive, L.M., Dierssen, M., Vallina, I.F., Insausti, R., Flórez, J., 1998. Hippocampal volume and neuronal number in Ts65Dn mice: a murine model of Down syndrome. Neurosci. Lett. 253, 1-4.

Jacobs, B., Scheibel, A.B., 2002. Regional dendritic variation in primate cortical pyramidal cells. In: Schüz, A., Miller, R. (Eds.), Cortical Areas; Unity And Diversity. Taylor and Francis, London, pp. 111-131.

Jones, T.A., Klintsova, A.Y., Kilman, V.L., Sirevaag, A.M., Greenough, W.T., 1997. Induction of multiple synapses by experience in the visual cortex of adult rats. Neurobiol. Learn. Mem. 68, 13-20.

Kasai, H., Matsuzaki, M., Noguchi, J., Yasumatsu, N., Nakahara, H., 2003. Trends Neurosci.. Structure-stability-function relationships of dendritic spines 26, 360-368.

Kaufmann, W.E., Worley, P.F., Taylor, C.V., Bremer, M., Isakson, P.C., 1997. Cyclooxygenase 2 expression during rat neocortical development and in Rett syndrome. Brain Dev. 19, 25-34.

Kaufmann, W.E., 1999. Cytoskeletal determinants of dendritic development and function: implications for mental retardation. Devl. Neuropsychol. 16, 341-346.

Kaufmann, W., Moser, H.W., 2000. Dendritic anomalies in disorders associated with mental retardation. Cereb. Cortex 10, 981-991.

Kemper, T.L., 1988. Neuropathology of Down syndrome. In: Nadel, L. (Ed.), The psychobiology of Down syndrome. MIT Press, Cambridge, MA, pp. 269-289.

Kim, C.B.Y., Pier, L.P., Spear, P.D., 1997. Effects of ageing on numbers and sizes of neurons in histochemically defined subregions of monkey striate cortex. Anat. Rec. 247, 119-128.
Kishnani, P.S., Sullivan, J.A., Walker, B.K., Spiridigliozzi, G.A., Doraiswamy, P.M., Krishnan, K.R.R., 1999. Cholinergic therapy for Down's syndrome. Lancet 353, 1064-1065.

Kossel, A., Lowel, S., Bolz, J., 1995. Relationships between dendritic fields and functional architecture in striate cortex of normal and visually deprived cats. J. Neurosci. 15, 3913-3926.

Kurt, M.A., Davies, D.C., Kidd, M., Dierssen, M., Florez, J., 2000. Synaptic deficit in the temporal cortex of partial trisomy 16 (Ts65Dn) mice. Brain Res. 858, 191-197.

Lange, A.W., Molkentin, J.D., Yutzey, K.E., 2004. DSCR1 gene expression is dependent on NFATc1 during cardiac valve formation and colocalizes with anomalous organ development in trisomy 16 mice. Dev. Biol. 266, 346-360.

Lendvai, B., Stern, E.A., Chen, B., Svoboda, K., 2000. Experience-dependent plasticity of dendritic spines in the developing rat barrel cortex in vivo. Nature 404, 876-881.

Lobaugh, N.J., Karaskov, V., Rombough, V., 2001. Piracetam therapy does not enhance cognitive functioning in children with Down syndrome. Arch. Pediatr. Adolesc. Med. 155, 442-448.

Lott, I.T., Osann, K., Doran, E., Nelson, L., 2002. Down syndrome and Alzheimer disease. Arch. Neurol. 59, 1133-1136.

Maletic-Savatic, M., Malinow, R., Svoboda, K., 1999. Rapid dendritic morphogenesis in CA1 hippocampal dendrites induced by synaptic activity. Science 283, 1923-1927.

Marin-Padilla, M., 1972. Structural abnormalities of the cerebral cortex in human chromosomal aberrations. A Golgi study. Brain Res. 44, 625629.

Marin-Padilla, M., 1976. Pyramidal cell abnormalities in the motor cortex of a child with Down's syndrome: a Golgi study. J. Comp. Neurol. 16, 6381.

Martínez-Cué, C., Baamonde, C., Vallina, I.F., Lumbreras, M.A., Dierssen, M., Flórez, J., 1999. Reduced responsiveness of Ts65Dn mice to pain. Neuroreport 10, 1119-1122.

Martinez-Cue, C., Baamonde, C., Lumbreras, M., Paz, J., Davisson, M.T., Schmidt, C., Dierssen, M., Florez, J., 2002. Differential effects of environmental enrichment on behavior and learning of male and female Ts65Dn mice, a model for Down syndrome. Behav. Brain Res. 134, 185-200.

Mastroiacovo, P., 2002. Epidemiology of Down syndrome in the third millenium. 2nd International conference EDSA 'The Adult with Down Syndrome. A new Challenge for Society', San Marino.

McManus, M.T., Sharp, P.A., 2002. Gene silencing in mammals by small interfering RNAs. Nat. Rev. Genet. 3, 3737-3746.

Miyabara, S., Sugihara, H., Yonemitsu, N., Yun, K., 1984. Comparative study of phenotypic expression of mice trisomy 16 by different female strains: attempt at an animal model for human trisomy 21. Cogn. Anomal. 24, 283-292.

Montero, J.J., Flórez, J., Baamonde, C., Vallina, I.F., García-Calatayud, S., Dierssen, M., 1996. Valoración ecográfica mediante doppler pulsado de la función cardíaca en el ratón Ts65Dn, un modelo murino de síndrome de Down. Rev. Síndrome Down 13, 31-32.

Moran, T.H., Capone, G.T., Knipp, S., Davisson, M.T., Reeves, R., Gearhart, J.D., 2002. The effects of piracetam on cognitive performance in a mouse model of Down's syndrome. Physiol. Behav. 77, 403-409.

Olson, L.E., Roper, R.J., Baxter, L.L., Carlson, E.J., Epstein, C.J., Reeves, R.H., 2004. Down syndrome mouse models Ts65Dn, Ts1Cje, and Ms1Cje/Ts65Dn exhibit variable severity of cerebellar phenotypes. Dev. Dyn. 230, 581-589.

Oster-Granite, M.L., 1986. The neurobiologic consequences of autosomal aneuploidy in mice and men. Brain Res. Bull. 16, 767-771.

Parnavelas, J.G., Lynch, G., Brecha, N., Cotman, C.W., Globus, A., 1974. Spine loss and regrowth in hippocampus following deafferentation. Nature 248, 71-73.

Penzes, P., Beeser, A., Chernoff, J., Schiller, M., Eipper, B.A., Mains, R.E., Huganir, R.L., 2003. Rapid induction of dendritic spine morphogenesis by trans-synaptic ephrinB-EphB receptor activation of the Rho-GEF kalirin. Neuron 37, 263-274. 
Persico, A.M., Schindler, C.W., Davis, S., Ambrosio, E., Uhl, G., 1998. Medial prefrontal cortical injections of c-fos antisense oligonucleotides transiently lower c-Fos protein and mimic amphetamine withdrawal behaviours. Neuroscience 82, 1115-1129.

Petit, T.L., LeBoutillier, J.C., Gregorio, A., Libstug, H., 1988. The pattern of dendritic development in the cerebral cortex of the rat. Dev. Brain Res. 41, 209-219.

Pham, T.M., Ickes, B., Albeck, D., Soderstrom, S., Granholm, A.C., Mohammed, A.H., 1999. Changes in brain nerve growth factor levels and nerve growth factor receptors in rats exposed to environmental enrichment for one year. Neuroscience 94, 279-286.

Pinter, J.D., Eliez, S., Schmitt, J.E., Capone, G.T., Reiss, A.L., 2001. Neuroanatomy of Down's syndrome: a high-resolution study. Am. J. Psychiatry 58, 1659-1665.

Purpura, D.P., 1974. Dendritic spine dysgenesis and mental retardation. Science 186, 1126-1128.

Prasher, V.P., Huxley, A., Haque, M.S., Down syndrome Ageing Study Group, 2002. Int. J. Geriatr. Psychiatry 17, 270-278.

Prinz, M., Prinz, B., Schulz, E., 1997. The growth of non-pyramidal neurons in the primary motor cortex of man: a Golgi study. Histol. Histopathol. $12,895-900$.

Pritchard, M.A., Kola, I., 1999. The gene dosage effect hypothesis versus the amplified developmental instability hypothesis in Down syndrome. J. Neural. Transm. Suppl. 57, 293-303.

Prusky, G.T., Reidel, C., Douglas, R.M., 2000. Environmental enrichment from birth enhances visual acuity but not place learning in mice. Behav. Brain Res. 114, 11-15.

Rampon, C., Jiang, C.H., Dong, H., Tang, Y.P., Lockhart, D.J., Schultz, P.G., Tsien, J.Z., Hu, Y., 2000. Effects of environmental enrichment on gene expression in the brain. Proc. Natl. Acad. Sci. U.S.A. 97, $12880-12884$.

Raz, N., Torres, I.J., Briggs, S.D., Spencer, W.D., Thornton, A.E., Loken, W.J., Gunning, F.M., McQuain, J.D., Driesen, N.R., Acker, J.D., 1995. Selective neuroanatomic abnormalities in Down's syndrome and their cognitive correlates: evidence from MRI morphometry. Neurology 45, 356-366.

Reeves, R.H., Irving, N.G., Moran, T.H., Wohn, A., Kitt, C., Sisodia, S.S., Schmidt, C., Bronson, R.T., Davisson, M.T., 1995. A mouse model for Down syndrome exhibits learning and behaviour deficits. Nat Genet. 11 (2), 177-184.

Reymond, A., Marigo, V., Yaylaoglu, M.B., Leoni, A., Ucla, C., Scamuffa, N., Caccioppoli, C., Dermitzakis, E.T., Lyle, R., Banfi, S., Eichele, G., Antonarakis, S.E., Ballabio, A., 2002. Human chromosome 21 gene expression atlas in the mouse. Nature 420, 582-586.

Richtsmeier, J.T., Baxter, L., Reeves, R., 2000. Parallels of craniofacial development in Down syndrome and Ts65Dn mice. Develop. Dynam. 217, 137-145.

Rogers, D.C., Fisher, E.M., Brown, S.D., Peters, J., Hunter, A.J., Martin, J.E., 1997. Behavioral and functional analysis of mouse phenotype: SHIRPA, a proposed protocol for comprehensive phenotype assessment. Mamm. Genome 8, 711-713.

Roizen, N.J., Patterson, D., 2003. Down's syndrome. Lancet 361, 12811289.

Rose, S.P., 2002. Smart drugs: do they work? Are they ethical? Will they be legal?. Nat. Rev. Neurosci. 3, 975-979.

Rosenzweig, M.R., Bennett, E.L., Diamond, M.C., 1972. Brain changes in relation to experience. Sci. Am. 226, 22-29.

Ruiz de Azua, I., Lumbreras, M.A., Zalduegui, A., Baamonde, C., Dierssen, M., Florez, J., Salles, J., 2001. Reduced phospholipase C-beta activity and isoform expression in the cerebellum of TS65Dn mouse: a model of Down syndrome. J. Neurosci. Res. 66, 540-545.

Sago, H., Carlson, E.J., Smith, D., Kilbridge, J., Rubin, E.M., Mobley, W., Epstein, C.J., Huang, T., 1998. Ts1Cje, a partial trisomy 16 mouse model for Down syndrome, exhibits learning and behavioral abnormalities. Proc. Natl. Acad. Sci. U.S.A. 95, 6256-6261.

Sago, H., Carlson, E.J., Smith, D.J., Rubin, E.M., Crnic, L.S., Huang, T.T., Epstein, C.J., 2000. Genetic dissection of region associated with beha- vioral abnormalities in mouse models for Down syndrome. Pediatr. Res. 48, 606-613.

Salman, M.S., 2002. Systematic review of the effect of therapeutic dietary supplements and drugs on cognitive function in subjects with Down syndrome. Eur. J. Paediatr. Neurol. 6, 213-219.

Saran, N.G., Pletcher, M.T., Natale, J.E., Cheng, Y., Reeves, R.H., 2003. Global disruption of the cerebellar transcriptome in a Down syndrome mouse model. Hum. Mol Genet. 12, 2013-2019.

Schulz, E., Scholz, B., 1992. Neurohistological findings in the parietal cortex of children with chromosome aberrations. J. Hirnforsch 33, 3762.

Segal, M., 1995. Morphological alterations in dendritic spines of rat hippocampal neurons exposed to $N$-methyl-D-aspartate. Neurosci. Lett. 193, 73-76.

Shapiro, B.L., 1999. The Down syndrome critical region. J. Neural. Transm. Suppl. 57, 41-60.

Shapiro, M.B., Haxby, J.V., Grady, C.L., 1992. Nature of mental retardation and dementia in Down syndrome: study with PET, CT, and neuropsychology. Neurobiol. Aging 13 (6), 723-734.

Shepherd, G.M., 1996. The dendritic spine: a multifunctional integrative unit. J. Neurophysiol. 75, 2197-2210.

Shim, K.S., Lubec, G., 2002. Drebrin, a dendritic spine protein, is manifold decreased in brains of patients with Alzheimer's disease and Down syndrome. Neurosci. Lett. 324, 209-212.

Siarey, R.J., Stoll, J., Rapoport, S.I., Galdzicki, Z., 1997. Altered long-term potentiation in the young and old Ts65Dn mouse, a model for Down syndrome. Neuropharmacology 36, 1549-1554.

Siarey, R.J., Carlson, E.J., Epstein, C.J., Balbo, A., Rapoport, S.I., Galdzicki, Z., 1999. Increased synaptic depression in the Ts65Dn mouse, a model for mental retardation in Down syndrome. Neuropharmacology 38, 1917-1920.

Smart, F.M., Halpain, S., 2000. Regulation of dendritic spine stability. Hippocampus 10, 542-554.

Smith, D.J., Zhu, Y., Zhang, J., Cheng, J.F., Rubin, E.M., 1995. Construction of a panel of transgenic mice containing a contiguous 2-Mb set of $\mathrm{YAC} /$ P1 clones from HSA21q22.2. Genomics 27, 425-434.

Smith, D.J., Stevens, M.E., Sudanagunta, S.P., Bronson, R.T., Makhinson, M., Watabe, A.M., O’Dell, T.J., Fung, J., Weier, H.U., Cheng, J.F., Rubin, E.M., 1997. Functional screening of $2 \mathrm{Mb}$ of HSA21q22.2 in transgenic mice implicates minibrain in learning defects associated with Down syndrome. Nat. Genet. 16, 28-36.

Somia, N., Verma, I.M., 2000. Gene therapy: trials and tribulations. Nat. Rev. Genet. 1, 91-98.

Song, E., Lee, S.K., Wang, J., Ince, N., Ouyang, N., Min, J., Chen, J., Shankar, P., Lieberman, J., 2003. RNA interference targeting Fas pprotects mice from fulminant hepatitis. Nat. Med. 9, 347-351.

Sorra, K.E., Harris, K.M., 1998. Stability in synapse number and size at $2 \mathrm{~h}$ after long-term potentiation in hippocampal area CA1. J. Neurosci. 18, 658-671.

Sorra, K.E., Harris, K.M., 2000. Overview on the structure, composition, function, development, and plasticity of hippocampal dendritic spines. Hippocampus 10, 501-511.

Stepanyants, A., Hof, P.R., Chklovskii, D.B., 2002. Geometry and structural plasticity of synaptic connectivity. Neuron 34, 275-288.

Suetsugu, M., Mehraein, P., 1980. Spine distribution along the apical dendrites of the pyramidal neurons in Down's syndrome. A quantitative Golgi study. Acta Neuropathol. (Berl.) 50, 207-210.

Takashima, S., Becker, L.E., Armstrong, D.L., Chan, F., 1981. Abnormal neuronal development in the visual cortex of the human fetus and infant with down's syndrome. A quantitative and qualitative Golgi study. Brain Res. 225, 1-21.

Takashima, S., Ieshima, A., Nakamura, H., Becker, L.E., 1989. Dendrites, dementia and the Down syndrome. Brain Dev. 11, 131-133.

Teller, J.K., Russo, C., DeBusk, L.M., Angelini, G., Zaccheo, D., DagnaBricarelli, F., Scartezzini, P., Bertolini, S., Mann, D.M., Tabaton, M., Gambetti, P., 1996. Presence of soluble amyloid beta-peptide precedes amyloid plaque formation in Down's syndrome. Nat. Med. 2, 93-95. 
Tomizuca, K., Yoshida, H., Uejima, H., Kugoh, H., Sato, K., Ohguma, A., Hayasaka, M., Hanaoka, K., Oshimura, M., Ishida, I., 1997. Functional expression and germline transmission of a human chromosome fragment in chimaeric mice. Nat. Genet. 16, 133-143.

Toni, N., Buchs, P.A., Nikonenko, I., Bron, C.R., Muller, D., 1999. LTP promotes formation of multiple spine synapses between a single axon terminal and a dendrite. Nature 402, 421-425.

Torasdotter, M., Metsis, M., Henriksson, B.G., Winblad, B., Mohammed, A.H., 1998. Environmental enrichment results in higher levels of nerve growth factor mRNA in the rat visual cortex and hippocampus. Behav. Brain Res. 93, 83-90.

Torre, E., McNiven, M.A., Urrutia, R., 1994. Dynamin 1 antisense oligonucleotide treatment prevents neurite formation in cultured hippocampal neurons. J. Biol. Chem. 269, 32411-32417.

Volkmar, F.R., Greenough, W.T., 1972. Rearing complexity affects branching of dendrites in the visual cortex of the rat. Science 176, 1145-1147.

Vuksic, M., Petanjek, Z., Rasin, M., Kostovic, I., 2002. Perinatal growth of prefrontal layer III pyramids in Down syndrome. Pediatr. Neurol. 27, 36-38.

Wang, J., Zugates, C.T., Liang, I.H., Lee, C.H., Lee, T., 2002. Drosophila Dscam is required for divergent segregation of sister branches and suppresses ectopic bifurcation of axons. Neuron 33, 557-559.
Wenger, G.R., Schmidt, C., Davisson, M.T., 2004. Operant conditioning in the Ts65Dn mouse: learning. Behav. Genet. 34, 105-119.

Weitzdoerfer, R., Dierssen, M., Fountoulakis, M., Lubec, G., 2001. Fetal life in Down syndrome starts with normal neuronal density but impaired dendritic spines and synaptosomal structure. J. Neural. Transm. 61, 59-70.

Wisniewski, K.E., Kida, E., 1994. Abnormal neurogenesis and synaptogenesis in Down syndrome brain. Dev. Brain Dysfunct. 7, 289-301.

Yang, E.J., Ahn, Y.S., Chung, K.C., 2001. Protein kinase Dyrk1 activates cAMP response element-binding protein during neuronal differentiation in hippocampal progenitor cells. J. Biol. Chem. 276, 39819-39824.

Yuste, R., Bonhoeffer, T., 2001. Morphological changes in dendritic spines associated with long-term synaptic plasticity. Annu. Rev. Neurosci. 24, 1071-1089.

Zapata, A., Capdevila, J.L., Tarrason, G., Adan, J., Martínez, J.M., Piulat, J., Trullás, R., 1997. Effects of NMDA-R1 antisense oligodeoxynucleotide administration: behavioral and radioligand binding studies. Brain Res. $745,114-120$.

Ziv, N.E., Smith, S.J., 1996. Evidence for a role of dendritic filopodia in synaptogenesis and spine formation. Neuron 17, 91-102. 